\title{
Biodiesel Synthesis through the Non-Alcohol Route using the Immobilized Lipase Enzyme from Bacillus subtilis as Biocatalyst
}

\author{
Afrah Alatas ${ }^{\mathrm{a}, *}$, Dwini Normayulisa Putri ${ }^{\mathrm{a}}$, Meka Saima Perdani ${ }^{\mathrm{a}}$, Tania Surya Utami ${ }^{\mathrm{a}}$, Heri Hermansyah ${ }^{\mathrm{a}}$ \\ ${ }^{a}$ Department of Chemical Engineering, Faculty of Engineering, Universitas Indonesia, Depok, West Java, 16424, Indonesia \\ Corresponding author: *alatasafrah@gmail.com
}

\begin{abstract}
Biodiesel is one alternative energy that might be promising to substitute the petroleum-based fuel due to its biodegradability and less toxic level. Biodiesel can be synthesized through the non-alcohol route by substituting the alcohol with methyl acetate using lipase enzyme as the Biocatalyst, which may give less by-product during the reaction. In this research, lipase from Bacillus subtilis has been produced and prepared in a crude, dry and immobilized form. It is used as the Biocatalyst for biodiesel synthesis. Several variables were investigated for obtaining the optimum condition in producing biodiesel, including the form of lipase enzyme, the variation of molar ratio between oil and methyl acetate, and the enzyme concentration. The immobilized Bacillus subtilis lipase enzyme loading was also calculated to know how many percent of the lipase is successfully immobilized. The biodiesel produced using lipase from Bacillus subtilis will then be compared with the biodiesel produced using Candida rugosa commercial lipase. Based on the experimental, the immobilized lipase with 1:12 of oil to methyl acetate and enzyme concentration of $2 \%$ gives the highest biodiesel yield among the others, as much as $\mathbf{5 3 . 9 9 \%}$. This yield was higher than the biodiesel produced using Candida rugosa lipase. In conclusion, the immobilized lipase from Bacillus subtilis is one of the promising Biocatalyst for biodiesel production.
\end{abstract}

Keywords - Bacillus subtilis; biodiesel; immobilization; interesterification; lipase.

\section{INTRODUCTION}

Biodiesel is one of the alternative energy sources that substitutes petroleum-based diesel fuel [1]. Biodiesel has some advantages over petroleum-based diesel fuel, such as biodegradable and less toxic [2]. Biodiesel could be a promising alternative energy source for substituting petroleum (or fossil) based diesel fuel since, in general, it can improve environmental conditions by reducing the number of greenhouse gases.

Biodiesel is formed by the transesterification reaction of triglyceride containing fatty acids and alcohol, resulting in fatty acid methyl ester (FAME) and glycerol [3]. The biodiesel itself is represented with FAME. In biodiesel synthesis, catalysts are commonly used in the reaction. The catalysts can be an acid or base, such as sulfuric acid and sodium hydroxide. However, there are still drawbacks to producing biodiesel using the acid/base catalyst, for instance, the contamination from saponification reaction. This unwanted product will lead to a decrease in biodiesel yield [4].

As a solution, a lipase enzyme might be a promising catalyst for synthesizing biodiesel [5]. Using lipase as
Biocatalyst to produce biodiesel could give more potential than using the chemical (acid or alkaline) catalysts since no complex operations are required for the by-product recovery than the production using acid-alkaline catalysts [6]. Besides, some issues related to saponification, purification, washing, and neutralization during the lipase-catalyzed reaction process [7]. Furthermore, the lipase-catalyzed biodiesel synthesis produces higher purity of the product (in this case, esters) [7].

Lipase is one of the most commonly used enzymes in industries as a catalyst [8]. Lipases are classified into the hydrolase group [9], which has a function to catalyze the hydrolysis of insoluble triacylglycerols to free fatty acids, mono and diacylglycerols, and glycerol. Lipase can catalyze the esterification, interesterification, and transesterification reactions [5]. Lipases also have an essential role in the bioenergy field for biodiesel production, which is the most recent use nowadays [10].

However, lipase is easily deactivated in an alcohol reaction [11]. It is possible to change the alcohol route into a nonalcohol route to prevent enzyme deactivation [4]. Methyl acetate is one of the chemicals that can substitute methanol to react with triglycerides [12]. 
Some research has been conducted for biodiesel production from around the world. Biodiesel synthesis using the immobilized Candida Antarctica lipase has been done by Ognjanovic et al. [13]. In their research, both the alcohol and non-alcohol route was conducted using the sunflower oil substrate. The synthesis was done for 50 hours and at a temperature of $45^{\circ} \mathrm{C}$, with $3 \%$ of lipase concentration, resulting in $99.6 \%$ biodiesel yield. Similar research was also done by Usai et al. [14] for producing biodiesel through a nonalcohol route. The reaction was done with oil to methyl acetate ratio of 1:20 and a constant enzyme concentration of $8 \%$. This research resulted in $80 \%$ of biodiesel conversion. Huang and Yunjun [15] did research regarding biodiesel synthesis through the non-alcohol route. The reaction was done at a speed of $240 \mathrm{rev} / \mathrm{min}$ and 20 hours, resulting in $98 \%$ biodiesel conversion.

In this research, biodiesel will be produced through the non-alcohol route using lipase enzyme from Bacillus subtilis. The lipase will also be produced in this research through the submerged fermentation technique. The fermentation process produced the lipase in a crude form and dried using the spray dryer, and immobilized using the adsorption-crosslinking technique. For biodiesel production, the lipases obtained in crude, dry and immobilized form will be used as the catalyst to react with triglyceride (represented by palm oil) and methyl acetate as acyl acceptor to be investigated which form of enzyme will result in a higher biodiesel yield. The oil to methyl acetate ratio and the lipase concentration are other variables to be investigated in this research.

This research aims to synthesize biodiesel through a nonalcohol route using the Bacillus subtilis lipase. Three different forms of the enzyme compare which form of the enzyme is better by variating the enzyme concentration and oil to methyl acetate molar ratio and obtain the most optimum condition for producing biodiesel using Bacillus subtilis lipase.

\section{MATERIAL AND METHOD}

This research was begun with lipase production from Bacillus subtilis, crude, dry, and immobilized. After producing the enzyme, the biodiesel synthesis was done using the Bacillus subtilis lipase previously produced. For the lipase production, starting from the microbe's sub-culture until the drying process, the steps were referred to Suci [16]. During lipase production, the cooking waste oil was used as a substrate for fermentation [16]. For the immobilization stage and the enzyme activity assay, the procedure was referred to Prabaningtyas et al. [17]. The biodiesel synthesis procedure was referred to as the procedure that has been done by Suci [16] and Hermansyah et al. [18], with a variation of oil to methyl acetate molar ratio and lipase enzyme concentration. Later, the biodiesel produced from each form of lipase will be compared to the biodiesel produced from Candida rugosa commercial lipase. The Bacillus subtilis isolate was purchased from InaCC LIPI, West Java, Indonesia, while the other chemicals were obtained from the Bioprocess Laboratory Universitas Indonesia.

\section{A. Sub-Culture and Pre-Culture of Bacillus subtilis}

Sub-culture of Bacillus subtilis was done in Nutrient Agar (NA) medium. First, the NA medium was dissolved into the distilled water and sterilized using an autoclave at temperature $121^{\circ} \mathrm{C}$ for 15 minutes. Next, the sterilized NA solution was transferred to the petri dish and inoculated along with the Bacillus subtilis isolate at $37^{\circ} \mathrm{C}$ for 24 hours.

Pre-culture of Bacillus subtilis was done in $50 \mathrm{~mL}$ Luria Bertani (LB) broth medium. First, the LB broth medium was dissolved into distilled water and sterilized using an autoclave temperature of $121^{\circ} \mathrm{C}$ for 15 minutes. After that, the subcultured microbe was inoculated into the sterilized LB broth and incubated at $30^{\circ} \mathrm{C}$ for the next 24 hours.

\section{B. Lipase Production by Submerged Fermentation}

The fermentation was conducted according to the optimum condition from Suci [16] with a slight modification. According to the referred paper, the additional nutrients used in the experiment were peptone and yeast extract as a nitrogen source, olive oil as the inducer, and $\mathrm{CaCl}_{2}$ as the metal source. The concentration for both peptone and yeast extract are $0.5 \%$ (w/v), while the concentration of olive oil and $\mathrm{CaCl}_{2}$ are $0.25 \%$ $(\mathrm{v} / \mathrm{v})$; and $10 \mathrm{mM}$, respectively. For the amount of substrate and inoculum, the concentration used for waste cooking oil was $4 \%(\mathrm{v} / \mathrm{v})$, while the inoculum concentration was $5 \%(\mathrm{v} / \mathrm{v})$. The sample was prepared in $500 \mathrm{~mL}$ of phosphate buffer medium. These nutrients were prepared along the fermentation substrate according to the desired amounts in a phosphate buffer of $0.1 \mathrm{M}$ with $\mathrm{pH}$ 7.5. Next, the mixture was sterilized in an autoclave for 15 minutes before the fermentation begins and adding the required amount of inoculum to the mixture. The fermentation was done in a shaker water bath at $30^{\circ} \mathrm{C}$ with level 3 shaker speed for 72 hours, or equivalent to 3 days.

\section{Lipase Extraction}

The extraction was done by centrifuging the sample using centrifugation at a speed of $4000 \mathrm{rpm}$ for 45 minutes. Next, the supernatant was filtered using filter paper and storing the samples at a temperature of $4^{\circ} \mathrm{C}$.

\section{Crude Lipase Activity Assay}

The activity test of lipase was done in a quantitative analysis using the titrimetric method and hydrolysis reaction. For this assay, olive oil was used as the substrate, which the triglyceride in olive oil will be hydrolyzed, resulting in free fatty acid (FFA). PVA was added as an emulsifier, and the reaction was done in a level 3 shaker water bath for 15 minutes at $37^{\circ} \mathrm{C}$. The FFA produced will be titrated using sodium hydroxide $(\mathrm{NaOH})$ until it turns its color into light pink. The color change indicates the titration endpoint has been reached. $\mathrm{NaOH}$ 's volume in the process will be noted at the end of the titration to calculate the mole of free fatty acid (FFA) produced. The amount of FFA produced is calculated using the following formula:

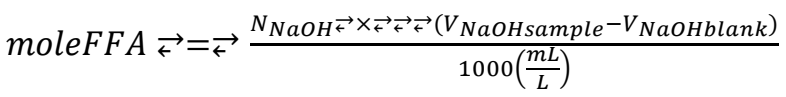

Then, the crude lipase activity unit is calculated using the following formula:

$$
\text { ActivityUnit }=\frac{F F \text { Amole }}{t(\min )} \times \frac{10^{6}\left(\frac{\mu \mathrm{mol}}{\mathrm{mol}}\right)}{\text { volumeofenzyme }}
$$




\section{E. Lipase Drying}

Some part of the crude enzyme was dried using the spray dryer equipment and skim milk powder as the additive to obtain the dried (powder) form of the lipase. The spray drying method and skim milk powder additive were chosen. According to Utami et al. [19], the powder's form resulting from this technique was more stable than the freeze-drying and maltodextrin additive. In this process, $12 \%(\mathrm{w} / \mathrm{v})$ of skim milk powder was added to the crude lipase as an additive. The spray drying process was done with an inlet temperature of $80^{\circ} \mathrm{C}$ and an outlet temperature of $130^{\circ} \mathrm{C}$. The output of this process is the powder form of Bacillus subtilis lipase.

\section{F. Dry Lipase Activity Assay}

The lipase activity assay was also done for the dry enzyme. The procedure is similar to the crude enzyme activity assay. However, the dry lipase should be first dissolved in phosphate buffer, and the reaction was done in 30 minutes, which is longer than the previous assay. The FFA produced was titrated using sodium hydroxide $(\mathrm{NaOH})$ until the color turns into light pink. In this step, the specific lipase activity unit was also calculated. The specific lipase activity unit is calculated using the following formula:

$$
\text { Spec. Act. Unit }=\frac{\text { ActivityUnit }}{\text { Conc.oflipase }\left(\frac{g}{m L}\right) \times 1000\left(\frac{m g}{g}\right)}
$$

The specific activity of lipase is presented as a unit per milligram of dry lipase $(\mathrm{U} / \mathrm{mg})$.

\section{G. Lipase Immobilization}

The immobilization of lipase was done using the adsorption-crosslinking method. It uses the anion resin microporous Lewatit MP-64 as the material support and glutaraldehyde as the crosslinking agent. The immobilization procedure was referred to Prabaningtyas et al. [17]. The dry enzyme was taken for 0.1 gram and dissolving into $10 \mathrm{~mL}$ of phosphate buffer. This lipase solution was added along 250 mg of resin Lewatit MP-64, reacting it in a shaker water bath at level 3 speed, $30^{\circ} \mathrm{C}$ for 4 hours. Next, glutaraldehyde with $0.5 \%$ concentration and $5 \mathrm{~mL}$ was added to the mixture and reacting it again in a shaker water bath for 20 minutes with the same operating condition as previous.

It should be noted that before adding the resin, after 4 hours of reaction and after 20 minutes of reaction, the enzyme sample was taken as the $C_{o}, C_{t}$ after adsorption, and $C_{t}$ after crosslinking, respectively. These data were taken to calculate the enzyme loading. After the immobilization procedure is completed, the lipase activity unit is also calculated with the same technique for calculating the activity unit of dry lipase.

\section{H. Enzyme Loading Calculation}

The samples taken from the immobilization procedure were analyzed its enzyme loading. According to Prabaningtyas et al. [17], enzyme loading is defined as the lipase concentration that is successfully immobilized during the adsorption and crosslinking, presented in a percentage form. The enzyme loading calculation was based on the Lowry method. Each sample's absorbance was measured using a UV-VIS spectrophotometer and calculating their concentration using the standard calibration curve. The enzyme loading was calculated using the following formula:

$$
X_{L}=\frac{C_{E}}{C_{0}} \times 100 \%
$$

Where

$$
C_{E}=C_{0}-C_{t}
$$

\section{Biodiesel Synthesis}

Biodiesel synthesis was done using the interesterification reaction between palm oil and methyl acetate, using the Bacillus subtilis lipase produced in three different forms (crude, dry, and immobilized). The reaction begins by heating the desired volume of palm oil at $40^{\circ} \mathrm{C}$ for 15 minutes and reacting it with methyl acetate with various molar ratios 1:3 and 1:12 in an Erlenmeyer flask. After reacting palm oil and methyl acetate, lipase was added with varying concentrations of $1 \%, 2 \%$, and $4 \%$ of the palm oil substrate. Next, the reaction was done in a shaker water bath, at temperature $40^{\circ} \mathrm{C}$, with level 5 speed for 50 hours. The data were analyzed using GC-MS (Gas Chromatography-Mass Spectrometry). The same procedure was also done for the biodiesel synthesis using Candida rugosa commercial lipase. However, before use, Candida rugosa lipase should be dissolved in a phosphate buffer with $\mathrm{pH}$ 7. After that, it can be used with the same procedure for biodiesel synthesis using Bacillus subtilis lipase.

\section{RESULTS AND DISCUSSION}

This section presents some research data and discusses the result of the research. The data are divided into four different parts: the data of lipase activity assay, biodiesel synthesis data using Bacillus subtilis and Candida rugosa, and the data of enzyme loading percentage from the immobilized Bacillus subtilis lipase.

\section{A. Lipase Activity Assay Result}

The lipase activity assay was done in the quantitative method using acid-base titration. Figure 1 below shows the lipase activity assay from crude, dry and immobilized Bacillus subtilis lipase.

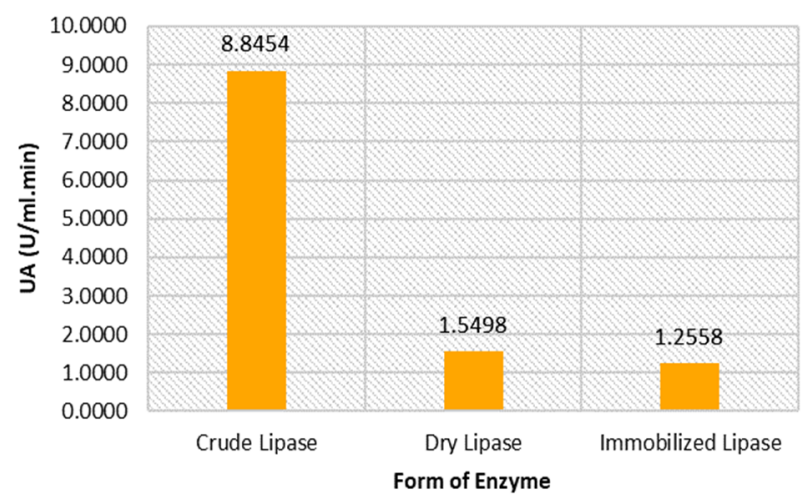

Fig. 1 Enzyme activity unit comparison of crude, dry, and immobilized Bacillus subtilis lipase

According to Figure 1, the lipase activity unit tends to be lower after the drying and immobilization steps. This lower number could be due to a high temperature that can denature the enzyme since it is known that the lipase enzyme is sensitive to heat. The time required for hydrolyzing the olive oil substrate might be impactful to the activity unit of lipase. The time required for hydrolyzing the olive oil using both dry 
and immobilized lipase is longer than the time required for hydrolyzing the olive oil using a crude enzyme.

According to the calculation formula, the reaction time required is inversely proportional to the enzyme activity unit. Therefore, once the reaction time increased, then the enzyme activity unit's result could be decreased. The specific activity unit of lipase is also calculated, presented in Figure 2 below.

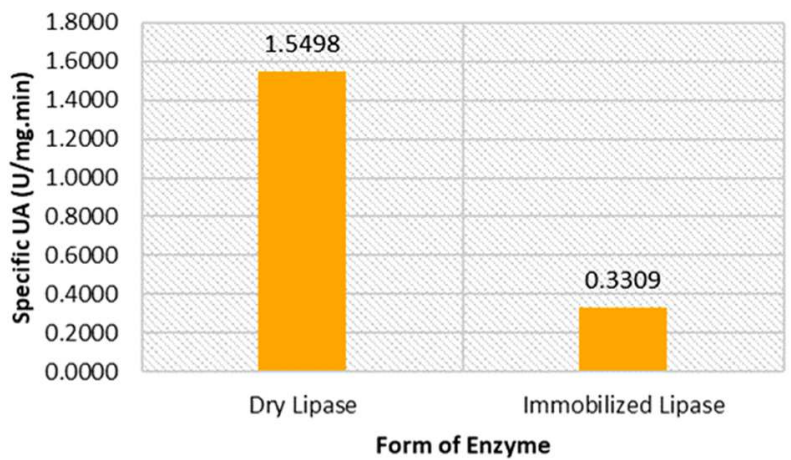

Fig. 2 Specific enzyme activity unit comparison of dry and immobilized Bacillus subtilis lipase

According to Figure 2, it can be seen that the specific activity unit of dry lipase is higher than the immobilized enzyme. This result is related to the Lowry method for quantifying the protein content in both enzymes, in which the physical difference can be seen. The dry lipase has a darker blue color than the immobilized lipase. Based on the Lowry analysis method, the darker the blue color means the higher the protein content in the sample. The skim-milk powder mixed the dry enzyme before the drying process began, resulting in higher protein in the dry enzyme. Thus, dry lipase has a higher specific activity unit due to its higher protein content.

\section{B. Biodiesel Synthesis Results}

This section will elaborate on the result of the biodiesel synthesis using the crude, dry, and immobilized Bacillus subtilis lipase. The biodiesel synthesis result from Candida rugosa is also presented in this section as a comparison.

1) Biodiesel Synthesis using Crude Lipase from Bacillus subtilis: Figure 3 shows the biodiesel synthesis experiment results using Bacillus subtilis lipase in crude form. Based on Figure 3, the highest biodiesel conversion is at 4\% of enzyme concentration when the oil to methyl acetate molar ratio is $1: 3$, with $10.74 \%$ of biodiesel conversion achieved. The data also shows that the biodiesel yield increased as the enzyme concentration rises in both 1:3 and 1:12 oil to methyl acetate ratio. On the other hand, at $1 \%$ of enzyme concentration, there is a very slight difference in biodiesel yield when oil to methyl acetate ratio at 1:12 to the 1:3 molar ratio, which can be considered tend to be constant. This experiment result is similar to the research conducted by Huang and Yunjun [15], in which the FAME produced tends to decrease as the oil to methyl acetate molar ratio increases. This phenomenon could be occurred the excess amount of methyl acetate will lead to the production of excessive oil dilution; thus, the biodiesel yield is reduced.

2) Biodiesel Synthesis using Dry Lipase from Bacillus subtilis: Figure 4 illustrates the biodiesel synthesis results using the dry Bacillus subtilis lipase. Based on Figure 4, the highest biodiesel yield is achieved when the oil to methyl acetate at $1: 3$ ratio with $2 \%$ of enzyme concentration.

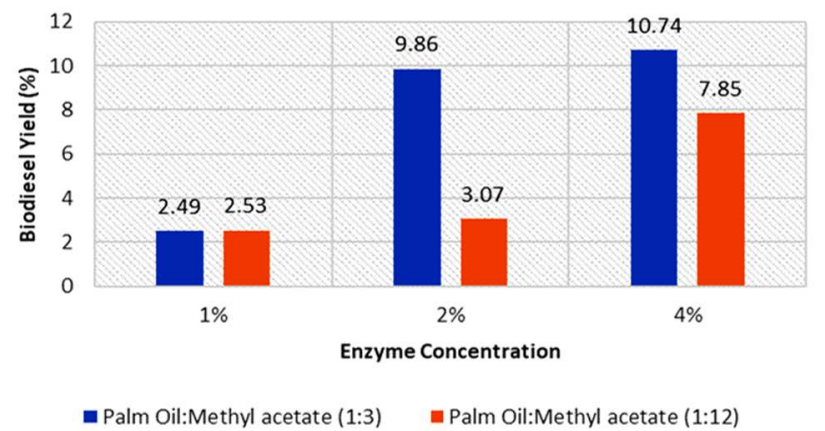

Fig. 3 Biodiesel synthesis yield using Bacillus subtilis crude lipase

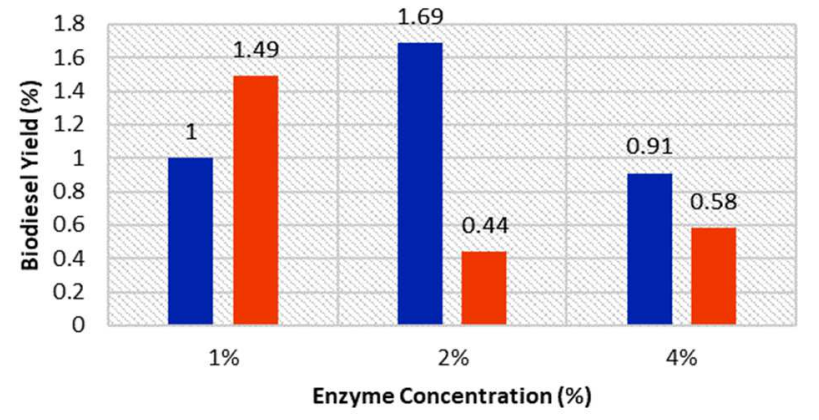

- Palm Oil:Methyl acetate (1:3) a Palm Oil:Methyl acetate (1:12)

Fig. 4 Biodiesel synthesis yield using Bacillus subtilis dry lipase

The data above shows a fluctuation of biodiesel yield as the enzyme concentration is getting higher. The data fluctuation happened because the dry enzyme was added directly to the reactants without dissolving it in buffer solution. Since a higher enzyme concentration means the higher weight of the enzyme, it is harder for the higher percentage to be dissolved completely. Moreover, this might be due to the shaker speed not being high enough during the reaction, resulting in the dry enzyme still in the Erlenmeyer flask's bottom.

3) Biodiesel Synthesis using Immobilized Lipase from Bacillus subtilis: Figure 5 presents the biodiesel synthesis result using the immobilized form of Bacillus subtilis lipase. According to the graph, the higher the molar ratio, the higher the biodiesel yield will be achieved. On the other hand, there is a slight decrease at $2 \%$ of enzyme concentration and $4 \%$ of enzyme concentration when the oil to methyl acetate ratio is $1: 12$. Generally, compared to the enzyme in a crude and dry form, the immobilized enzyme dramatically increases the biodiesel produced. This result happened because it is believed that doing an immobilization of the enzyme may increase its resistance to several environmental changes, including temperature changes. Similar phenomena also occurred to the research reported by Marno [4], showing that the higher the enzyme concentration, the higher the biodiesel yield. 


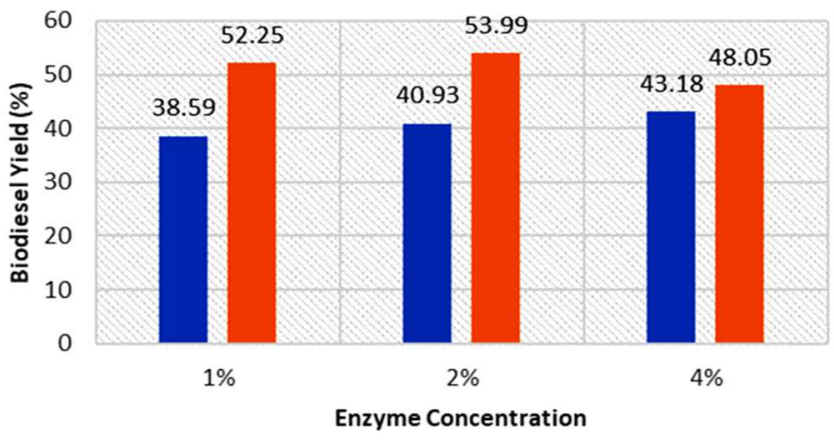

- Palm Oil:Methyl acetate (1:3) a Palm Oil:Methyl acetate (1:12)

Fig. 5 Biodiesel synthesis using Bacillus subtilis immobilized lipase

On the other hand, the slight decrease of biodiesel yield for oil to methyl acetate ratio 1:12 when the enzyme concentration $4 \%$ could be caused by the enzyme has reached its saturated stage. It thus tends not to produce biodiesel much as when the enzyme concentration at $2 \%$. This phenomenon has also occurred in the research reported by Huang and Yunjun [15]. According to the research, the biodiesel yield's saturation amount was achieved when the enzyme concentration reached $30 \%$. Higher than that concentration, the biodiesel yield tends to be constant, or even a slight decrease.

4) Biodiesel Synthesis using Commercial Lipase from Candida rugosa: Figure 6 below shows the biodiesel synthesis yield using Candida rugosa lipase. It can be seen that based on the graph, the highest biodiesel yield was obtained from 1:3 palm oil to methyl acetate ratio at $2 \%$ enzyme concentration, which is $18.86 \%$. The lowest was obtained at the same reactant ratio but with a higher enzyme concentration. A significant fluctuation also occurred to the data, which on both oil to methyl acetate ratio at $2 \%$ of enzyme concentration showed their highest value of biodiesel yield. In contrast, a relatively low result shows when the enzyme concentrations are at $1 \%$ and $4 \%$. This phenomenon occurred since the enzyme may have reached its saturated stage at a particular concentration and lead the enzyme not to catalyze the reaction properly.

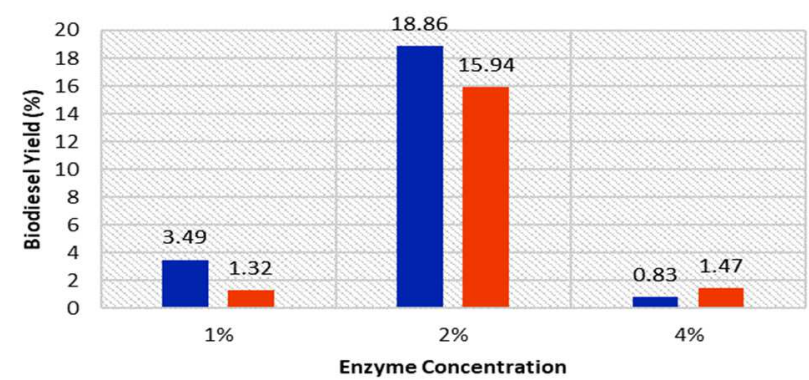

- Palm Oil:Methyl acetate (1:3) = Palm Oil:Methyl acetate (1:12)

Fig. 6 Biodiesel synthesis yield using Candida rugosa commercial lipase

\section{Results Comparison with Other Researcher}

This research is also compared to the other researcher, whether from Universitas Indonesia researchers or international ones. Table 1 below shows the comparison of biodiesel synthesis results to the researchers from Universitas Indonesia.

TABLE I

COMPARISON OF BIODIESEL SYNTHESIS RESULTS FROM UNIVERSITAS INDONESIA RESEARCHER

\begin{tabular}{ccc}
\hline Researcher (Year) & Biodiesel Yield (\%) & Ref. \\
\hline Marno (2008) & $86.55 \%$ & {$[4]$} \\
Rizkiyadi (2008) & $75 \%$ & {$[12]$} \\
Prameshwari (2011) & $24.56 \%$ & {$[20]$} \\
Sipangkar (2012) & $99.79 \%$ & {$[21]$} \\
Authors (2019) & $53.99 \%$ & This study \\
\hline
\end{tabular}

In most previous research, the Candida rugosa commercial lipase was used as the Biocatalyst for producing biodiesel. According to Table 1, the highest biodiesel conversion was achieved by Sipangkar [21], with $99.79 \%$ of biodiesel conversion. Another research conducted by Marno [4] showed a high biodiesel yield, which is $86.55 \%$. Same as Marno [4], research conducted by Rizkiyadi [12] also uses the Candida rugosa lipase in suspension form, with a difference of the substrate that used the waste cooking oil. In this comparison, Hermansyah et al. [20] achieved the lowest biodiesel conversion, with only $24.56 \%$ of biodiesel conversion. This result is still even lower than the result obtained by the Author, which is $53.99 \%$.

Table 2 below shows the comparison of biodiesel synthesis resulted from Author to the international researchers. According to Table 2, some international researchers tend to produce a very high amount of biodiesel. The highest biodiesel yield is $99.6 \%$, research done by Ognjanovic et al. [13]. The immobilized Candida Antarctica lipase was used as biocatalyst and palm oil as the substrate in their study. This result is followed by Huang and Yunjun [15], Duraiarasan and Vijay [24], and Desikan et al. [23] with 98\%, 95.36\%, and 90\% of biodiesel yield, respectively. For the rest of the researchers, the biodiesel yield resulted are all below $90 \%$, including the biodiesel yield resulted by Author. However, the lowest biodiesel conversion resulted comes from [22], which is only $33.3 \%$. In their research, Rhizopus oryzae lipase's suspension form was used as the catalyst, creating a difference from the other researcher that commonly used the immobilized form of lipase.

TABLE II

COMPARISON OF BIODIESEL SYNTHESIS RESULTS FROM INTERNATIONAL RESEARCHER

\begin{tabular}{ccc}
\hline Researcher (Year) & Biodiesel Yield (\%) & Ref. \\
\hline Ognjanovic (2008) & $99.6 \%$ & {$[13]$} \\
Vipin et al. $(2016)$ & $33.3 \%$ & {$[22]$} \\
Usai et al $(2010)$ & $80 \%$ & {$[14]$} \\
Huang and Yunjun (2008) & $98 \%$ & {$[15]$} \\
Desikan et al. (2013) & $90 \%$ & {$[23]$} \\
Duraiarasan and Vijay (2014) & $95.36 \%$ & {$[24]$} \\
Authors (2019) & $53.99 \%$ & This \\
& & study \\
\hline
\end{tabular}

D. Enzyme Loading Results

Figure 7 shows the enzyme loading calculation results of the immobilized Bacillus subtilis enzyme. 


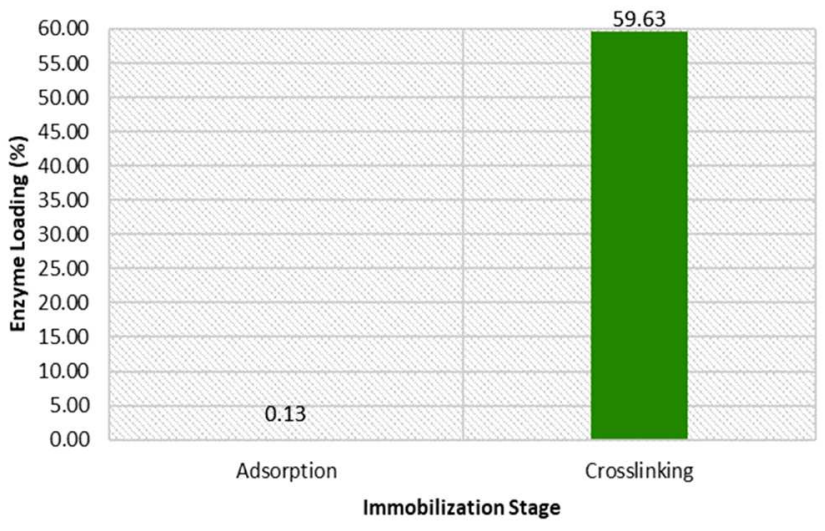

Fig. 7 Enzyme loading data from Bacillus subtilis immobilized enzyme

Based on the result above, there is a massive difference between the enzyme loading during the adsorption and crosslinking stage. The enzyme loading percentage during the adsorption stage is 0.13 , which is a deficient number. The low enzyme loading percentage could be caused by fragile and less stable bonds formed, named the Van Der Waals and hydrogen bond. In contrast, a massive difference is seen in the enzyme loading percentage during the crosslinking immobilization stage at $59.63 \%$. This phenomenon occurred due to the resin's anion clusters $(\mathrm{OH}-)$ that react to the glutaraldehyde, which has a role as the crosslinking agent.

Therefore, the immobilization of the enzyme by adsorption alone is not enough and should be combined with another immobilization technique. In this case, the crosslinking method is combined with the adsorption method, resulting in a higher enzyme loading percentage.

\section{CONCLUSION}

From the research done and elaborated its procedure and data, there are some things to be concluded. It can be concluded that the lipase from Bacillus subtilis can be immobilized using the adsorption-crosslinking method, thus resulting in $53.99 \%$ of biodiesel yield when the oil to methyl acetate ratio is $1: 12$, and the enzyme concentration used is $2 \%$. This research showed a good result compared to the Candida rugosa commercial lipase. It only resulted in $18.86 \%$ of biodiesel yield as its highest value.

\section{NOMENCLATURE}

$\begin{array}{ll}\mathrm{N} & \text { Normality } \\ \mathrm{V} & \text { Volume } \\ \mathrm{t} & \text { Time } \\ \mathrm{X}_{\mathrm{L}} & \text { Enzyme loading } \\ \mathrm{C} & \text { Concentration }\end{array}$

$\mathrm{N}$
$\mathrm{mL}$
minute
$\%$
$\mathrm{~g} / \mathrm{mL}$

\section{Subscripts}

$0 \quad$ Initial condition, at $\mathrm{t}=0$

$\mathrm{E} \quad$ Immobilized enzyme

$\mathrm{t}$ condition at a certain time $\mathrm{t}$

\section{ACKNOWLEDGEMENT}

The authors would like to thank you for the research support provided by Universitas Indonesia and the Ministry of Research, Technology and the Higher Education Republic of Indonesia through Basic Research Grant 2020.

\section{REFERENCES}

[1] S.O. Kareem, E.I. Falokun, S.A. Balogun, O.A. Akinloye, and S.O. Omeike, "Enzymatic Biodiesel Production from Palm Oil and Palm Kernel Oil using Free Lipase," Egyptian Journal of Petroleum, vol. 26, no. 3, pp. 635-642, 2017.

[2] B. Thangaraj, P.R. Solomon, B. Muniyandi, S. Ranganathan, and L. Lin, "Catalysis in Biodiesel Production-a Review," Clean Energy, vol. 3, no. 1, pp. 2-23, 2018.

[3] A. Casas, M.J. Ramos, and A. Perez, "Production of Biodiesel through Interesterification of Triglycerides with Methyl Acetate," Essay, In Acetate: Versatile Building Block of Biology and Chemistry, pp. 143186, Nova Publisher, 2013.

[4] S. Marno, "Interesterifikasi Minyak Kelapa Sawit dengan Metil Asetat Menggunakan Biokatalis untuk Memproduksi Biodiesel," Bachelor thesis, Universitas Indonesia, Depok, Indonesia, 2008.

[5] F. Oliveira, C.E. Souza, V.R.O.L. Peclat, J.M. Salgado, B.D. Riberio, M.A.Z. Coelho, A. Venâncio, and I. Belo, "Optimization of Lipase Production by Aspergillus ibericus from Oil Cakes and Its Application in Esterification Reactions," Food and Bioprocess Processing, vol. 102, pp. 268-277, 2017.

[6] R.B.N. Prasad and B.V.S.K. Rao, "Lipase-Catalyzed Preparation of Biodiesel," Essay, In Handbook of Plant-Based Biofuels, pp. 199-212. Boca Raton: CRC Press, 2009.

[7] S.N. Gebremariam and J.M Marchetti, "Biodiesel Production Technologies: Review,” AIMS Energy, vol. 5, pp. 425-457, 2017.

[8] A. Salihu, M. Bala, and Md. Z. Alam, "Lipase production by Aspergillus niger using sheanut cake: An optimization study," Journal of Taibah University for Science, vol. 10, no. 6, pp. 850-859, 2016.

[9] P. Grunwald, Industrial Biocatalysis, Singapore: Pan Stanford Publ., 2015.

[10] L. Colla, A. Ficanha, J. Rizzardi, T. Bertolin, C. Reinehr, and J. Costa "Production and Characterization of Lipases by Two New Isolates of Aspergillus niger through Solid-state and Submerged Fermentation," Biomed Research International, pp. 1-9, 2015.

[11] H. Hermansyah, M. B. Faiz, and R. Arbianti, "Kinetic Study of Immobilized Whole-Cell Lipase Rhizopus Oryzae " Biocatalyst in Biodiesel Synthesis through Non-Alcohol Route," International Journal of Environmental Science and Development, vol. 6, no. 6, pp. 439-444, 2015.

[12] M.E. Rizkiyadi, "Reaksi Interesterifikasi Minyak Jelantah dengan Metil Asetat Menggunakan Katalis Candida rugosa Lipase untuk Memproduksi Biodiesel," Bachelor thesis, Universitas Indonesia, Depok, Indonesia, 2008.

[13] N. Ognjanovic, S. Saponjic, D. Bezbradica, and Z. Knežević, "Lipasecatalyzed biodiesel synthesis with different acyl acceptors," Acta Periodica Technologica, pp. 161-169, 2008.

[14] E.M. Usai, E. Gualdi, V. Solinas, and E. Battistel, "Simultaneous enzymatic synthesis of FAME and triacetyl glycerol from triglycerides and methyl acetate," Bioresource technology, vol. 101, pp. 7707-7712, 2010.

[15] Y. Huang and Y. Yunjun. "Lipase-Catalyzed Biodiesel Production with Methyl Acetate as Acyl Acceptor". Zeitschrift für Naturforschung. C, Journal of biosciences, vol. 63, pp. 297-302, 2008.

[16] M. Suci, "Produksi Lipase dari Bacillus subtilis dengan Fermentasi Terendam Menggunakan Substrat Minyak Jelantah,” Bachelor thesis, Universitas Indonesia, Depok, Indonesia, 2017.

[17] R.K. Prabaningtyas, D.N. Putri, T.S. Utami, and H. Hermansyah, "Production of immobilized extracellular lipase from Aspergillus niger by solid state fermentation method using palm kernel cake, soybean meal, and coir pith as the substrate," Energy Procedia, vol. 153, pp. 242-247, 2018.

[18] H. Hermansyah, M.I. Andikoputro, and A. Alatas, "Production of lipase enzyme from Rhizopus oryzae by solid state fermentation and submerged fermentation using wheat bran as substrate," vol. 2085, 2019.

[19] T.S. Utami, I. Hariyani, G. Alamsyah, and H. Hermansyah, "Production of Dry Extract Extracellular Lipase from Aspergillus Niger by Solid State Fermentation Method to Catalyze Biodiesel Synthesis," Energy Procedia, vol. 136, pp. 41-46, 2017.

[20] H. Hermansyah, R. Arbiati, and D.A Prameshwari, "Non-Alcohol Route of Biodiesel Synthesis from Used Cooking Oil Using Immobilized Biocatalyst in Packed Bed Reactor", Journal of Sustainable Energy \& Environment, vol. 2, pp. 1-5, 2011.

[21] I.A. Sipangkar, "Perbandingan Kinerja Biokatalis yang diimobilisasi Melalui Metode Entrapment Menggunakan Medium Support dari 
Kitin, Kitosan dan Zeolit untuk Sintesis Biodiesel Rute Non-Alkohol,” Bachelor thesis, Universitas Indonesia, Depok, Indonesia, 2012.

[22] V.C. Vipin, J. Sebastian, C. Muraleedharan, and A. Santhiagu, "Enzymatic Transesterification of Rubber Seed Oil Using Rhizopus oryzae Lipase,” Procedia Technology, vol. 25, pp. 1014-1021, 2016.

[23] S. Desikan, R. Kannan, K. Narayanan, M. Kumar, and P.T Kalaichelv, "Application of Immobilized Lipase Enzyme for the Production of
Biodiesel from Waste Cooking Oil," Asian Journal of Biological Sciences, vol. 6, pp. 322-330, 2013.

[24] S. Duraiarasan and M. Vijay, "Biodiesel production from Nannochloropsis oculata oil using immobilized lipase with methyl acetate as an acyl acceptor," BioTechnology: An Indian Journal, vol. 9, pp. 327-334, 2014. 